\title{
DE DE GRUYTER OPEN

\section{ANALYSIS OF THE HYDROCLIMATIC RISK PARAMETERS AT THE HIGH LEVEL OF THE TAZLĂUL SĂRAT RIVER IN 2016 YEAR}

\author{
Mihail Luca', Mihaela Avram²
}

\begin{abstract}
The paper presents an analysis of the hydrological risk parameters registered in June 2016 in the catchment area of the Tazlăul Sărat River. The studies and researches were carried out on the upper course of the river, in the area between Zemeş and Toderaş, the commune of Zemeş, Bacau county. The river basin of the Tazlăul Sărat River has been affected by several floods in recent years. The floods have morphologically modified the minor and the major river bed, which has influenced the stability of the county road and the river construction. The study focused on the analysis of precipitation and liquid flows over a period of 20 years. Processing of liquid flow data revealed more flood flows in the same year. In 2016 there was a flow of $342 \mathrm{~m} 3 / \mathrm{s}$ (probability of $3 \%$ ). The effects of the floods have materialized through the excessive degradation of shore defence works until their total destruction. The degradation of shore defence works has contributed to breaking the county road and limiting the road traffic. Parameters of hydroclimatic risk highlighted by research impose special conditions when designing shore defence works and protecting the road adjacent to the river.
\end{abstract}

Keywords: river, precipitation, flow, flood, shore defence works

\section{Introduction}

Over the last 20 years there have been a series of global climate changes, with direct impacts on the hydrological cycle. Such modifications are present on the territory of Romania and influence the annual distribution of precipitation and flows on hydrographic basins. The high value of the effects determines an important hydroclimatic risk in the flow and river levels. The hydrological changes

\footnotetext{
${ }^{1}$ Prof.Ph.D.eng. Professor, e-mail, ,Gh. Asachi” Technical University of Iasi, mluca2004@yahoo.com ${ }^{2} \mathrm{PhD}$ stud. "Gheorghe Asachi'Technical University of Iasi, Romania, mihaela.avram30@yahoo.com
} 
in the last years have influenced the way of the morphological evolution of the bed, the behaviour of existing structures in the river bed and river.

Hydrological risk factors affect the morphology of the bed, the stability of bed constructions (bridges, adjustments) and shore (shore defence works, dikes), as well as the habitat existing in the minor and major river bed. Disastrous floods have caused significant degradation of the social and economic objectives of the coastal area. The effect of the changes can be noticed immediately or occurs after a longer period of time (Luca M. and Stoenescu I., 2007, Enea A., et. alt. 2007).

Studies and research on a series of rivers in the Siret basin highlight the occurrence and evolution of some hydroclimatic risk factors.

A special situation is the hydrographical basin of the Tazlăul Sărat River, where the effects of the floods materialized through high damages. The high frequency of the floods caused a large amount of degradation of the hydro-technical works in the riverbed, as well as the riparian social and economic objectives (Vamanu E., 2002).

\section{MATERIAL AND RESEARCH METHOD}

The studies and researches were carried out on the Tazlăul Sărat River located in the Trotuş River Basin. The research material consists of hydrological, hydraulic, topographic, geotechnical, climatic, safety studies in buildings, etc. The data used in the study and research come from the following sources: water directories, the Romanian Water Cadastre Atlas, Siret Bacău Synthesis Reports, projects for river regularization works, technical expertise on the regulation of rivers and river defence constructions, etc.

Part of the data comes from field research conducted by the authors on the analyzed river sectors. Studies and research are conducted over different periods of time. Documentary studies, especially hydrological studies, are conducted over periods of 10 to 50 years.

The theoretical and experimental research was carried out in the following areas:

1. Research on hydrological and hydraulic parameters on the surface of the river basin considered in the study. Analyzed parameters were liquid flows, solid flows, levels, frequency of floods, flood areas, speeds etc.

2. Investigation of hydrological risk parameters with influence on bed morphology on studied river sector.

3. Effect of hydrological and hydraulic risk parameters with influence on shore defence and river construction works.

Primary data was processed using the statistical, hydrological and hydraulic calculation programs applicable to the case study. 


\section{GEOPHYSICAL PARAMETERS OF THE STUDY AREA}

The study area is situated on the upper course of the Tazlăul Sărat River, a tributary to the left of the Tazlău River. The river basin of the Tazlăul Sărat River is situated in the eastern part of the Eastern Carpathians, occupying the eastern slope of the Gosman Mountains and the western slope of the Tazlău Mountains. The lower southeast extremity of the hydrographic basin penetrates to the Tazlău Depression (Fig.1).

The relief is represented by mountainous ridges with medium and small altitudes belonging to the mountain groups Gosmanu and Tazlau Mountains (Fig. 1a). The Gosman Mountains represent an elongated main peak in the direction of the NWSE, from which separate secondary peaks separate from the tributaries of Tazlăul Sărat River separate. The main mountain peaks are the $1444 \mathrm{~m}$ Geoana crag, the Comanac with 1359 m, the Corbului with 1263 m, the Strigoiu with 1241 m and the Runcu Rău with $1183 \mathrm{~m}$. The mountain formations are composed of Tarcău sandstones (Avram M., 2016).

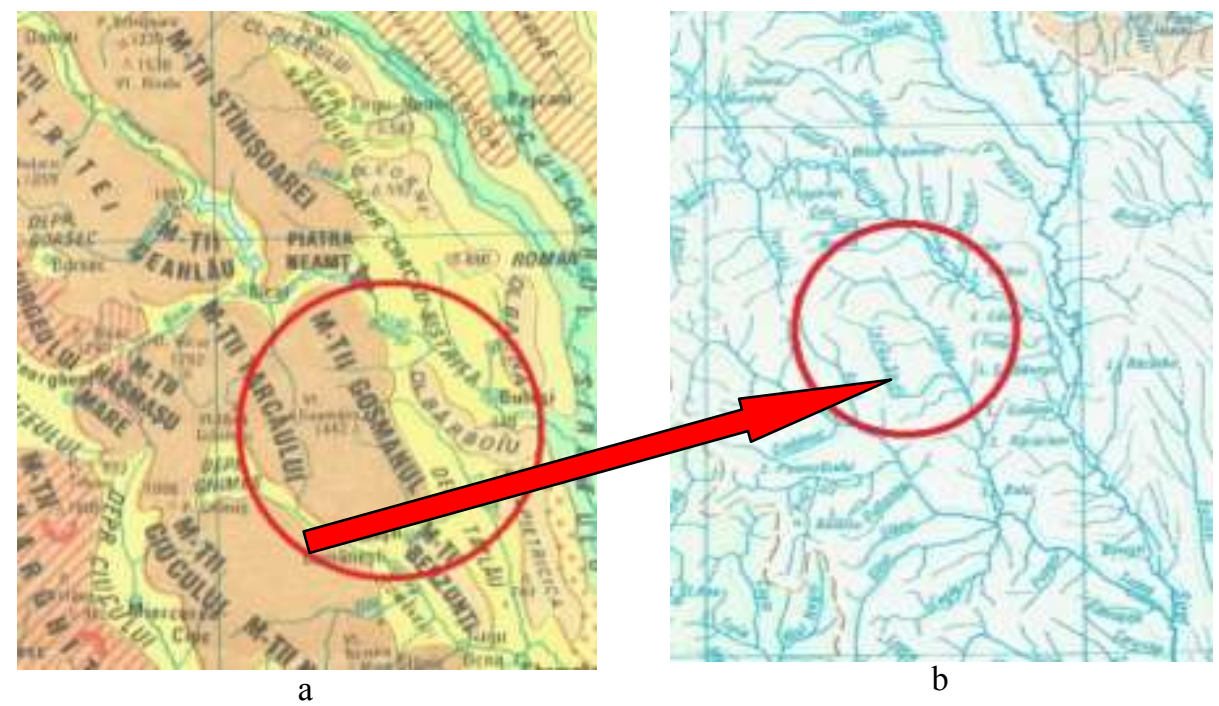

Fig. 1. Geophysical characteristics in the study area: a - relief areas; b - hydrographical network

The climate in the study area is temperate continental moderate, integrating into the mountainous climate of the Eastern Carpathians. The area is characterized by the influences of the continental climate in the east, of the sub-Atlantic and 
Atlantic north and west. The climate in the study area is temperate-continental, moderate, mountainous, with a multi-annual average air temperature of 7.50-8.00 ${ }^{0} \mathrm{C}$ in valleys and depressions. The annual rainfall increases with the altitude: 682 $1 / \mathrm{m}^{2}$ at Moineşti and $1039 \mathrm{l} / \mathrm{m}^{2}$ at Bolătău. The area is represented by torrential rain, especially during the hot season, which determines important floods in the hydrographic network (Avram M., 2016).

The catchment area of the Tazlăul Săratt River has a surface area of 211 $\mathrm{km}^{2}$. The length of the river is about $52 \mathrm{~km}$ and the slope is $1.17 \%$. The average altitude of the river basin is $430 \mathrm{~m}$. The Tazlăul Sărat River has an asymmetric basin, and the most tributaries are placed on the right from the Gosman-Geamanna peak (Fig. 1.b).

The Tazlăul Sărat River has two springs below Plaiul Floca, Obcina Geamăna, belonging to the Gosmanu-Geamăna-Rotundul mountain range. The Tazlăul Sărat River, a tributary on the right side of Tazlăul Mare near the village of Tescani. The maximum recorded historical flow was $284 \mathrm{~m}^{3} / \mathrm{s}$, recorded on 2005 July 13 (Avram M., 2016).

From the hydrological point of view, the study area belongs to Type C water regime characterized by a high leakage and a rich supply of high water rivers during the spring - summer period with frequent floods. In the cold season the flow of the streams decreases, and in conditions of low and prolonged temperatures conditions of the ice bridges are created over long distances.

The hydrostatic level of the groundwater is closely related to the precipitation regime due to the high permeability of the constituent formations of the terraces. In the contact area of the watercourses in the hydrographical basin there is a water exchange, which takes place in both directions (Luca M., 2016).

\section{ELEMENTS OF HYDROLOGICAL ANALYSIS IN THE TAZLĂULSĂRATHYDROGRAPHIC BASIN (H. B.)}

The research was carried out on the upper course of the Tazlăul Sărat River, which is a tributary to the right of the Tazlău River (Fig. 1). The Tazlăul Sărat River is the main collector of surface and underground waters in this area. The Tazlăul Sărat River flows into the Tazlău River between the Scorțeni and Helegiu hydrometric stations. The Tazlăul Sărat River, upstream of Lucăcești, has a length of $26 \mathrm{~km}$, a surface of the $95 \mathrm{~km}^{2}$ basin, an average slope of $36.9 \%$ and the length of the Zemeş locality area (Avram M., 2016).

In the research were used climatic data taken from meteorological stations located in the analyzed river basin. Hydrological data were collected from hydrometric stations located in characteristic sections on the river. 
The summer months are characterized in the river basin of the Tazlăul Sărat River through an abundant precipitation regime. This has substantially influenced the flow on the water courses in the study area. From the information presented of the A.B.A. Bacau shows that the highest precipitations in this area occurred in June on 2-4 day, 2016. The values recorded at the Lucăceşti H.S. were $54.40 \mathrm{l} / \mathrm{m}^{2}$ (Table 1). High precipitation values were recorded across the Trotus River basin, and their effect materialized through the formation of particularly destructive floods. It is worth mentioning that in the upper Tazlău River there have been extremely high precipitations, namely $93.61 / \mathrm{m}^{2}$ in Tazlău and $88.2 \mathrm{l} / \mathrm{m}^{2}$ at Scorţeni (Avram M., 2016).

Tab. 1. Precipitation $\left(l / \mathrm{m}^{2}\right)$ recorded in B.H. Tazlăul Sărat in the period 02.06-04.06.2016 (A.B.A. Siret, 2016)

\begin{tabular}{|c|c|c|c|c|c|}
\hline \multirow{2}{*}{$\begin{array}{c}\text { Hydrometric } \\
\text { station }\end{array}$} & 02.06 .2016 & 03.06 .2016 & 03.06 .2016 & 04.06 .2016 & \multirow{2}{*}{ Total } \\
\cline { 2 - 5 } & $06.00-18.00$ & $24.00-6.00$ & $18.00-24.00$ & $14.00-6.00$ & \\
\hline Lucăcești & 42,90 & 8,60 & 1,70 & 1,20 & 54,40 \\
\hline
\end{tabular}

The Tazlău Hydrographic Basin has a monitoring network consisting of 4 hydrometric stations, which are located in strategically selected areas depending on the shape of the basin (ABA Bacau, 2016). The analysis of the maximum flows recorded at the hydrometric stations in the river basin of the Tazlău River highlights high values (Table 2) (Avram M., 2016).

Tab. 2. Maximum flows in B.H of Tazlău and Tazlăul Sărat (Avram M., 2016)

\begin{tabular}{|c|c|c|c|c|c|c|c|c|}
\hline \multirow{2}{*}{$\begin{array}{l}\mathrm{Nr} . \\
\mathrm{crt}\end{array}$} & \multirow{2}{*}{ River } & \multirow{2}{*}{$\begin{array}{c}\text { Hydrometric } \\
\text { station }\end{array}$} & \multirow{2}{*}{$\underset{\left(\mathrm{m}^{3} / \mathrm{s}\right)}{\mathrm{Q}_{\max }}$} & \multirow{2}{*}{ Date $Q_{\max }$} & \multicolumn{4}{|c|}{ 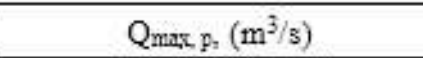 } \\
\hline & & & & & $1 \%$ & $2 \%$ & $5 \%$ & $10 \%$ \\
\hline 1 & Tazlău & Tazlău & 698 & 06.07 .1970 & 560 & 440 & 300 & 205 \\
\hline 2 & & Scorteni & 638 & 12.07 .2005 & 1010 & 805 & 575 & 405 \\
\hline 3 & & Helegiu & 1556 & 13.07 .2005 & 1540 & 1260 & 925 & 670 \\
\hline 4 & Tazlău1 Salt & Lucăcești & 514 & 12.07 .2005 & 540 & 425 & 290 & 200 \\
\hline
\end{tabular}

The flood wave formed in June 2016 on the Tazlăul Sărat River showed a flow rate of $342 \mathrm{~m}^{3} / \mathrm{s}$, a value approaching the $3 \%$ probability (Table 3, Fig. 2).

The flood on the Tazlăul Sărat River started on 02.06.2016, at 10.00, with a $69 \mathrm{~cm}$ share and a flow of $6.70 \mathrm{~m}^{3} / \mathrm{s}$. The peak of the flood was recorded on 02.06.2016, at 16.30, where the quota reached $360 \mathrm{~cm}$ and a maximum flow of $342 \mathrm{~m}^{3} / \mathrm{s}$. The $2.73 \mathrm{~m}$ flood gauge has overtaken the banks and has caused major 
floods and damage. The probability of exceeding the maximum flow rate (Luca M., 2016).

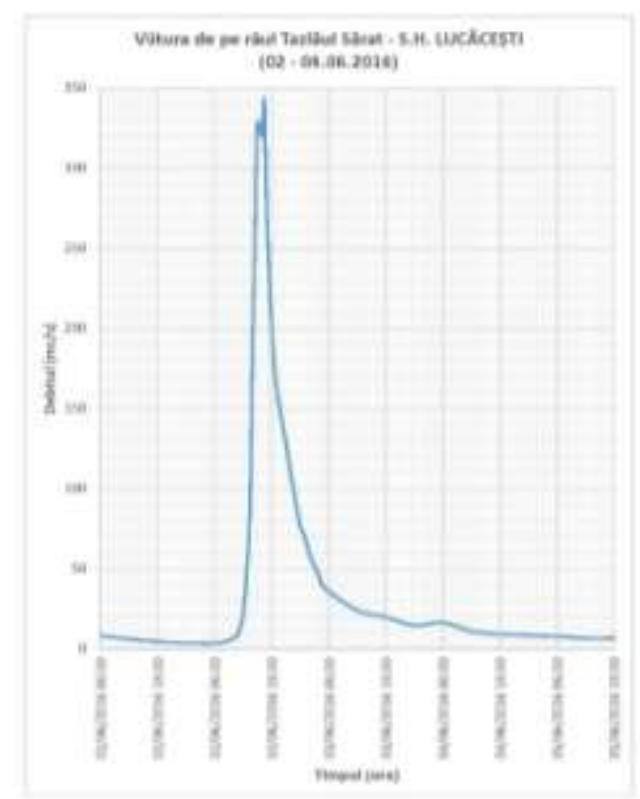

Fig. 2. The flood level hydrograph on the Tazlăul Sărat river, the Lucăceşti H.S.

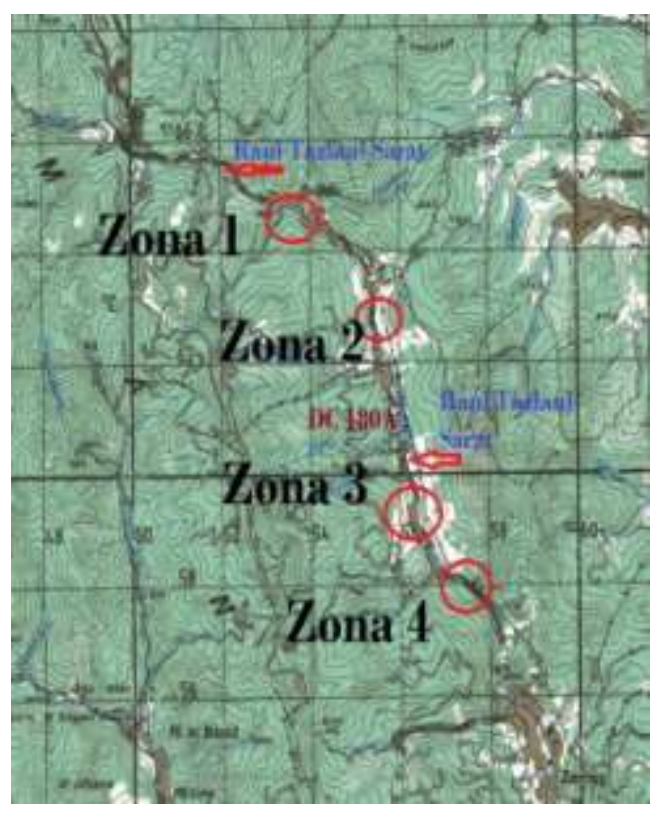

Fig. 3. Location of research areas on the Tazlăul Sărat River

Tab. 3. Flood data on the Tazlăul Sărat River in 02.06-04.06.2016, the Lucăceşti Hydrometric Station, (A.B.A. Siret, 2016)

\begin{tabular}{|c|c|c|c|c|}
\hline $\mathrm{H}_{\max }(\mathrm{cm})$ & $\mathrm{Q}\left(\mathrm{m}^{3} / \mathrm{s}\right)$ & $\mathrm{p}(\%)$ & Total precipitation, $\left(l / \mathrm{m}^{2}\right)$ & Remarks \\
\hline 360 & $\mathbf{3 4 2}$ & $\mathbf{3}$ & 85,9 & $+60 \mathrm{~cm} \mathrm{PC}$ \\
\hline
\end{tabular}

\section{RESULTS AND DISCUSSIONS}

The analysis of the effects of floods in June 2016, formed on the upper course of the Tazlăul Sărat River, was carried out in four characteristic areas. The criterion for selecting the areas of analysis was the value of flood damage and the impact on the environment and the human habitat. Areas of analysis are located inside and out of the localities Zemeş and Bolătău, on the Tazlăul Sărat River, Bacau County. The analysis considered the riverbed and the morphological changes formed, the behavior of the shore defence works, the stability of the DC 
$180 \mathrm{~A}$ communal road (ex DJ 117A), the stability of the economic and civil constructions in the riparian area, etc.

The four analyzed areas have the following location (Fig. 3) (Luca M., 2016):

1. The Toderaş area is located at $\mathrm{Km} 20+730.00$ on the DC $180 \mathrm{~A}$ road.

2. The Hârtopanu area is located at $\mathrm{Km} 18+640.00$ on the DC $180 \mathrm{~A}$ road.

3. The Chiosa area is located at $\mathrm{Km} 13+550.00$ on the DC 180A road.

4. The "Canton Silvic Maxim" area is located at Km $12+584.00$.

The DC 180A road is located on the banks of the Tazlăul Sărat River in all four areas of analysis. The road is asphalted and is in a relatively good state of exploitation. The road is in some sectors at the limit of contact with the river Tazlăul Sărat. For the protection of the road there have been breeding works on different lengths.

In the four analyzed areas, the floodplain produced the following risk situations for the river bed and the riparian environment:

- morphological changes of the riverbed, represented by river erosion in the area of the road location, deposits of alluvial and erosion in the thalweg (longitudinal grooves);

- shoreline degradation to protect the road and coastline objectives.

- the local degradation of the construction structure of the road in contact with the bank of the river and the limitation of the traffic on a road section;

- degradation of underpasses and bridges;

- oil pipelines dismantling in the river bank and at the roadside.

The degradation of shore defence works (lengths of 50-100 $\mathrm{m}$ in four study sections) is the result of erosions produced in the plane and vertical of the water flow at floods on the Tazlăul Sărat River. Three of the four analyzed areas presented, at the time of the study, shore defence works at various stages of operation (Toderaş, Hârtopanu and Forest Canton Maxim). Study area "Chiosa" did not present at the time of the analysis shore defence works.

The degradation of shore defence works has caused the erosion of the DC 180A road resistance structure (former DJ 117A). The DC 180A road was broken on lengths of 20-40 m, and the traffic was limited in one sense.

The basic geological features, plus the high degree of fragmentation, the large slopes, the strong deforestation effect and multiple anthropic actions (forestry, oil exploitation, transport, etc.) have favoured the development of destructive geomorphologic processes on the environment. The main morphological processes encountered in the study area are erosion, solid bedding, bed clinking, shore and slope landslides, etc.

The field analysis of the geotechnical structure in the river bank area highlighted the presence of massive gravel with intercalations of boulders. At the 
surface of the gravel mass lay thin layers of alluviums. Numerous sections of analysis along the Tazlăul Sărat River show hard rock layers. Water has shaped hard rocks, and the river bed has the appearance of a channel in some sectors (for example, the "Forest Canton Maxim" sector).

The synthetic results of field analysis in the four degraded areas have the following characteristics (Luca M., 2016):

Zone 1 - "Toderaş". The shore defence is executed from a simple concrete wall to the road elevation. The shore defence was degraded by $40-90 \%$ over a length of $60 \mathrm{~m}$. The flood waves have morphologically modified the Tazlăul Salt Riverbed in the "Toderaş" curvature area, causing the bedding to be dampened and the tallow descended, which influenced the shore defence behaviour and the degradation over time. The defence of the wall of a support wall made of simple concrete, located on the left bank in the curvature area, was completely destroyed in the central section (Fig. 4). The river also acts on small water on the bank, resulting in the continuous degradation of the structural components of the defence and further on the foundation layer of the communal road.

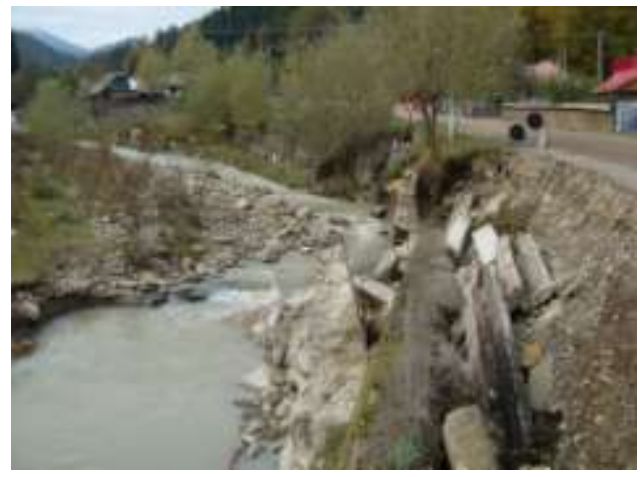

$\mathrm{a}$

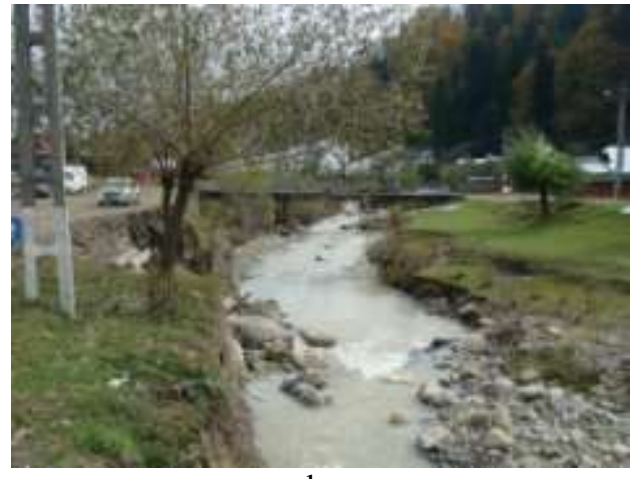

b

Fig. 4. General view of the morphology of the Tazlăul Sărat riverbed and the state of degradation of shore defence and DC 180A in Zone 1 "Toderaş": a - general view from downstream with highlighting the erosion of the road; b - upstream view (Oct 2016)

Zone 2 - "Hartopanu". In this area there was erosion of the bank downstream of the shore defence existing on the left bank of the Tazlăul Sărat River. The bank of the unprotected river in the curve area was eroded over a length of about $60.0 \mathrm{~m}$ and an entrance in the shore of 0.5-4.0 m. Erosion of the bank caused the degradation of the communal road structure and the loss of its stability.

Zone 3. "Chiosa". The Tazlăul Sărat River has a right curve in this area, after which it maintains a linear downstream (Fig. 5a). At the end of the curve, the riverbed and the left bank lie near the DC 180A communal road. 


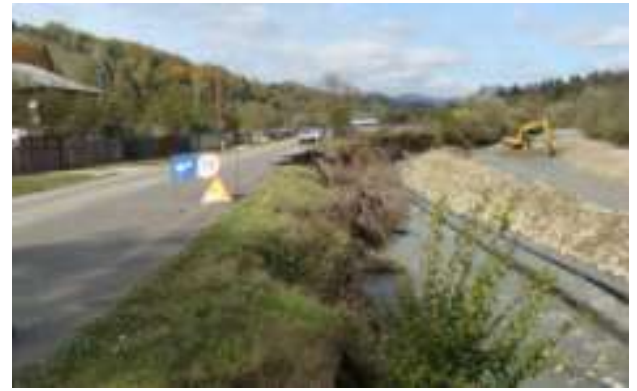

a

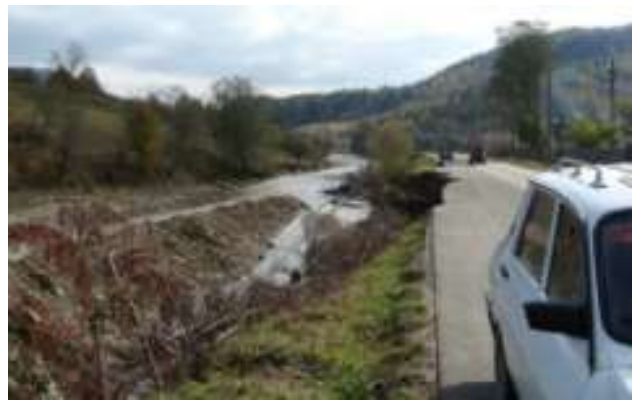

b

Fig. 5. The degradation phenomena of the riverbed in Zone 3, "Chiosa" after the flood in June 2016 on the Tazlăul Sărat River: a - upstream view of the river bed change and erosion; b - downstream view, highlighting oil piping and breaking the DC180A (photo Oct 2016)

The river develops a large hydraulic energy in the curve area, especially in times of flood, which generates a high value hydrodynamic force acting on

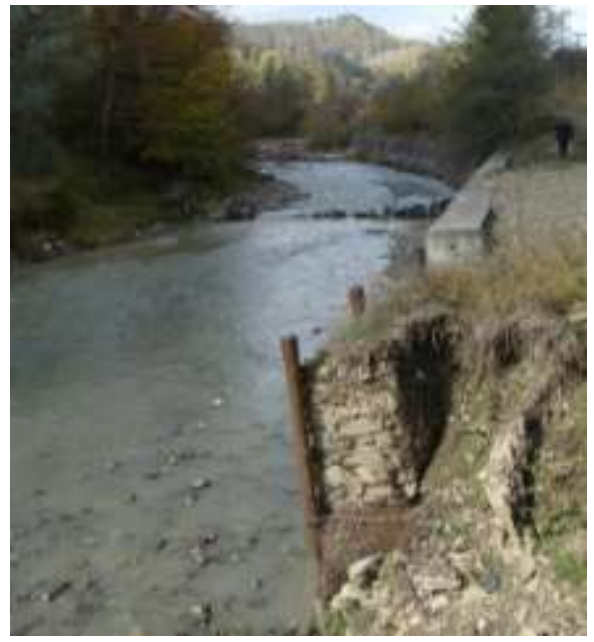

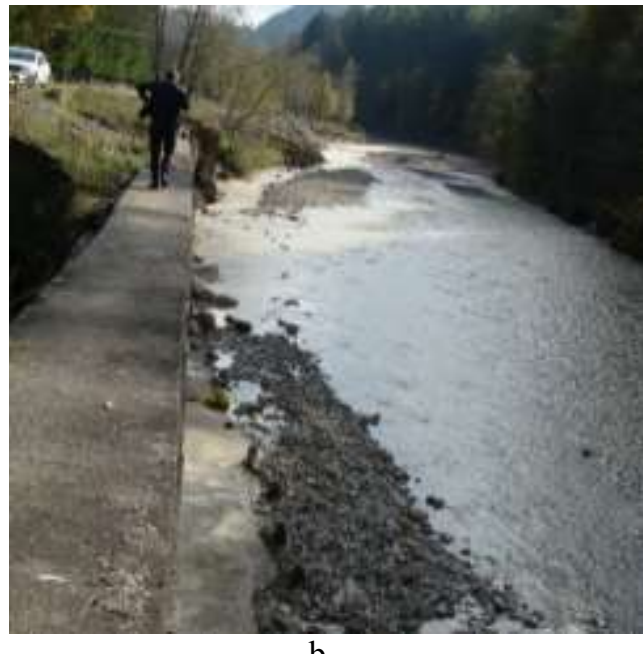

b

Fig. 6 - General view of the evolution bed of the Tazlăul Sărat River in area 4 "The Forest Canton Maxim": a - upstream view of the erosion area; b - downward view (photo Oct 2016)

shoreline and shoreline construction. The unprotected bank of the Tazlăul Sărat River was eroded on a length of $80 \mathrm{~m}$ and an entrance to the shore of $0.5-5.0 \mathrm{~m}$. 
The erosion phenomenon has caused road breakage and traffic constraint. Crude oil pipelines and electric cables are located (buried) in the shore area. The erosion of the shore caused the pipes to be cut off and suspended (Fig. 5.b). The field analysis did not reveal the presence of shore defence.

Zone 4. "Forest Canton Maxim". The Tazlăul Sărat River bed has an approximately trapezoidal shape in this area, with a bottom width of about $16.0 \mathrm{~m}$ and a height up to the crown of the shore defence of $4.0 \mathrm{~m}$. The left bank is vertical, being made by shore defence, and the right bank shows a slop slope 1: 0.5-0.8.

The first sub-area is located at the entrance to the analyzed riverbed sector, where the shore defence consists of a support wall made of plain concrete (foundation height $-1.00 \mathrm{~m}$, elevation height $3.00 \mathrm{~m}$, crown thickness $0.80 \mathrm{~m}$ ). The water flow in the curvature area has a high velocity, causing an erosion phenomenon of the thalweg and the left bank.

The lowering of the thalweg has influenced the stability of the support wall foundation. The foundation has been scattered over its entire length over a relatively long time (Fig. 7.b). The water penetrated under the foundation and made several flow paths in the massive bed of cohesive material of the bed. Through these voids, an infiltration stream or pressurized water jet was formed, which

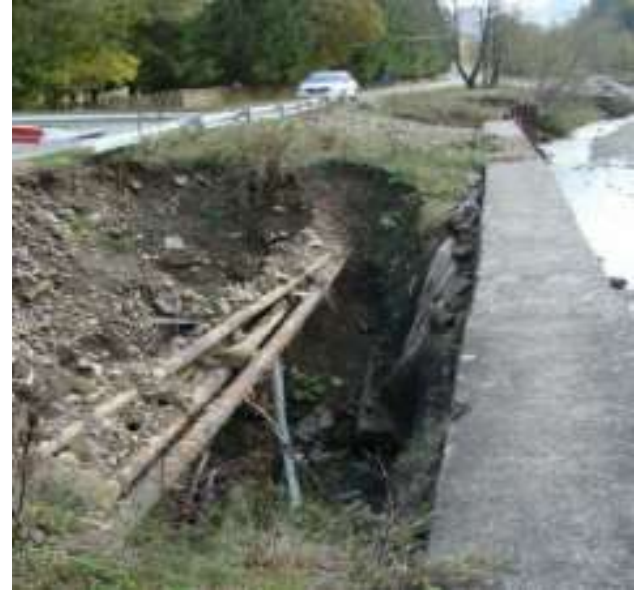

a

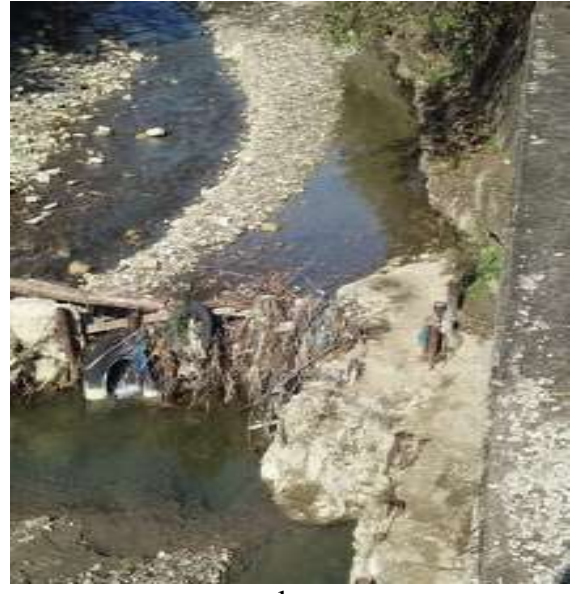

b

Fig. 7. Erosion phenomenon of the left bank after the flood in June 2016 on the Tazlăul Sărat River in Zone 4 "Forest Canton of Maxim": a - general view of the erosion zone behind the shore defence at the DC 180A limit; $b$ - fencing phenomenon in the shore defence foundation area (Oct. 2016)

washed the filler material behind the support wall (Figure 7.a). The erosion phenomenon of the water jet continued to the ground (Fig 7). The erosion pit 
behind the supporting wall reached a width of $4.80 \mathrm{~m}$, out of which $1.90-2.00 \mathrm{~m}$ have developed in the structure of the road (Luca M., 2016).

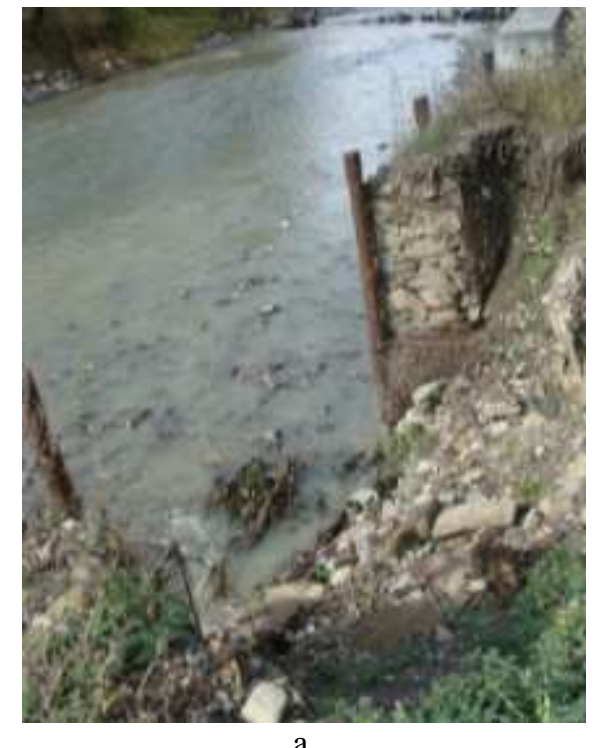

a

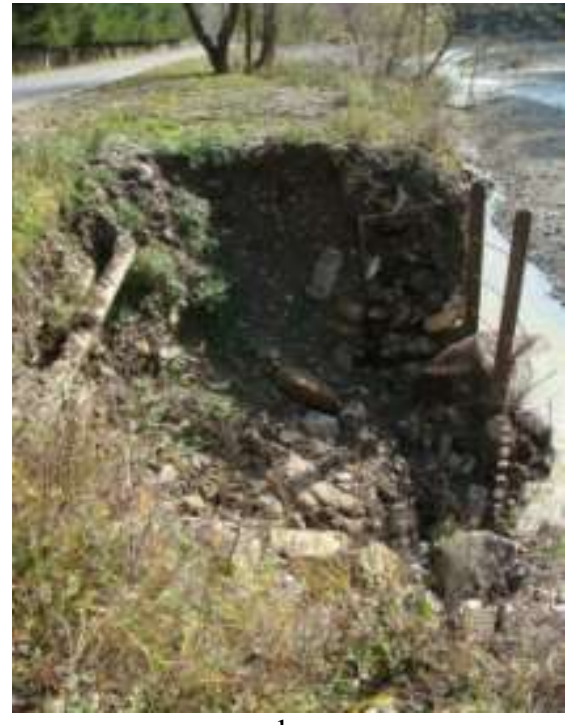

b

Fig. 8. Degradation of shore defence and erosion of the left bank of the Tazlăul Sărat River, the second erosion section, zone 4 " The Forest Canton Maxim": a - destruction of shore defence; b - upstream view (downstream river bed and unpacking of oil pipelines, Oct. 2016)

The second sub-area is located downstream to about $25.0 \mathrm{~m}$ from the first. The shore defence consists of a support wall made of gabion boxes. The water flow in the curvature area, guided by the simple concrete support wall, has created a strong erosion phenomenon here. The effect materialized through the destruction of the shore defence (gabion box support wall) on a length of about $15.0 \mathrm{~m}$ (Fig. 8). The erosion phenomenon continued until the road foundation (Luca M., 2016).

The degradation phenomenon of the left bank is influenced by the stable shape of the riverbed towards the right bank and by the limitation of the development of a meander to the left by the river. The hydraulic energy of the water stream turns into a mechanical deformation of the left bank in the curvature area. At the end of the road and on the bank of the river oil pipelines are buried. The erosion phenomenon of the bank and further on the road caused the pipes to be cut off and suspended. Pipeline degradation can lead to a strong oil pollution phenomenon on the Tazlăul Sărat River (Luca M., 2016). 


\section{Conclusions}

1. The Siret basin has been affected in the last 15 years by disastrous hydrological phenomena, which have greatly influenced river morphology, with significant influences on the riparian environment.

2. Between 2000 and 2016 they occurred in B.H. Of the Tazlăul Sărat River a series of floods with high flow rates and high frequency at reduced intervals, this morphologically modified the bed and eroded the regularization and defense of the shore.

3. The draft produced in June 2016 on the Tazlăul Sărat River recorded a flow rate of $342 \mathrm{~m}^{3} / \mathrm{s}$ (probability of $3 \%$ ), where the effects had a very destructive effect on the river bed and river area (especially on the DC road 180A).

\section{References}

Avram M., (2016). Cercetări privind impactul factorilor de risc hidroclimatic asupra proiectării, tehnologiilor de realizare şi exploatării lucrărilor de regularizare a râurilor - Studiu de caz. Raport de cercetare 2. Univ. Tehnică „Gheorghe Asachi” din Iaşi.

Enea A., Hapciuc O.E., Iosub M., Minea I., Romanescu G. (2017). Water quality assessment in three mountainous watersheds from eastern Romania (Suceava, Ozana and Tazlău rivers). Environmental Engineering and Management Journal, 16(3):605-614.

Ichim I., Bătucă D., Rădoane M., Duma D., (1989), Morfologia şi dinamica albiilor de râuri, Editura Tehnică București.

Luca, M., (2016). Expertiză tehnică „Consolidare mal drum DC180a in zonele afectate de inundațiile din mai-iunie 2016, respectiv punct Toderaș, Hârtopanu, Chiosa şi Canton Silvic Maxim, comuna Zemeș, județul Bacău". SC POLIAS-INSTAL Iaşi.

Luca, M., Stoenescu, I., (2007). Current Issues Concerning Regularization Works Behavior under Disaster Conditions, International Conference „Disaster and Pollution Monitoring - IC.DPM. 3", 1-2 nov. Iaşi, 93-98 pp.

Ujvari I., (1972). Geografia apelor României. Edit. Ştiinţifică, București.

Vamanu E., Olariu P., (2002). Riscuri hidroclimatice in Spaţiul hidrografic Siret in contextul modificărilor geografice. Culegere de lucrări, Ses. Ştiinț. anuală INMH Bucureşti.

*** (1983), Geografia României, vol. I şi II, Ed. Academiei, Bucureşti.

*** A.B.A. SIRET-Bacău „Rapoartele de sinteză privind apărarea împotriva inundațiilor, fenomenelor hidrometeorologice periculoase, accidentelor la construcții hidrotehnice și poluărilor accidentale din județul Bacău, pentru anii 1991, 2004, 2005, 2010, 2016.

*** Ministerul Mediului, (1992). Atlasul cadastrului apelor din România.

***http://www.rowater.ro/dasiret/default.aspx. 